\title{
Pääkirjoitus
}

\section{Kalevala Korusta ja kulttuuriperinnön valikoinnista}

\author{
Antti Lindfors \& Heidi Henriikka Mäkelä
}

$\mathrm{S}$ aimme viime syksynä seurata, kuinka Kalevalaisten Naisten Liiton omistama Kalevala Koru lanseerasi uuden ilmeen ja ja otti suurieleisesti käyttöönsä kalevala.fi-domainin. Yrityksen mainonnassaan käyttämät pseudokalevalamittaiset ja strategisen hämärästi Kalevalan mytologiaan liittyvät tekstit närkästyttivät joitain, sillä niihin liitettiin negatiivisia mielikuvia esimerkiksi kaupallisuudesta, epäautenttisuudesta ja -tarkkuudesta. Keskustelu yrityksen ympärillä heräsi jälleen keväällä 2021, joskin hieman eri syystä, kun Kalevala Koru puuttui pienen Kalevala kartalle -matkailubrändin toimintaan uhkailemalla oikeustoimilla, mikäli yritys käyttäisi viestinnässään Kalevala Koruun sekoitettavissa olevia elementtejä (HS 2.3.2021). Patentti- ja rekisterihallitus hylkäsi Kalevala Korun tekemän valituksen toukokuussa 2021, ja Ikitaival-niminen yritys saa jatkaa sekä Kalevala-nimen käyttämistä brändinsä nimessä, hannunvaakunaa logossaan ja myös korutuotteiden markkinointia (HS 5.5.2021). Emme tässä pääkirjoituksessa puutu tapauksen juridisiin näkökohtiin näiden julkista puintia pidemmälti. Tarkastelemme sen sijaan lyhyesti Kalevala Korun viimeaikaisiin toimiin ja sen herättämään julkiseen keskusteluun punoutunutta moraalis-ideologista problematiikkaa ja sen suhdetta kulttuuriperintöön liittyvään menneisyyden valikointiin.

Kansallismuseossa säilytettäviin arkeaologisiin löytöihin perustuva Kalevalaisten Naisten Liiton ideoima ja rahoittama korumallisto - Kalevala Korun ensimmäinen - lanseerattiin markkinoille juuri ennen toista maailmansotaa. Malliston takana oli voimakas nationalistinen agenda, jossa hyödynnettiin ajalle suosittuun medievalistiseen tapaan keskiaikaista kuvastoa ja ajatusta "suomalaisesta muinaisuudesta". (Fewster 2006, 384-391.) Kulttuuriperintöja vaikkapa arkeologien autenttisuuskeskusteluista ammentaen sekä esimerkiksi materiaalisuuteen liitetyn menneisyyden tunnun (pastness) käsitettä (esim. Holtorf 2013; Ikäheimo \& Äikäs 2017) hyödyntäen tätä yhtiön korujen taustalla olevaa prosessia voisi tarkastella hyvinkin pitkällisesti. Olennaisena päätelmänä prosessista voinee kuitenkin sanoa sen, että arkeologisia löytöjä ja kansanrunoaineistoja ei voida rinnastaa toisiinsa mitenkään ongelmattomasti (ks. myös Immonen 2006): koruista ei voi tulkita Kalevalaa tai toisinpäin, vaikka korujen alkuperäiset käyttäjät rautakaudella tai keskiajalla ovat ehkä tunteneet ja esittäneet myös kansanrunoja.

Tämä saattaa kuulostaa tutkijoille tyypilliseltä saivartelulta yhteiskunnallisessa ja kulttuurisessa tilanteessa, jossa Kalevala Koru on varsin etabloitunut yhtiö ja jossa Kuutar löytyy 
korulippaasta jos toisestakin. Se kuitenkin valottaa samantapaisia kalevalamittaisten runojen, Kalevalan ja (menneiden) laulukulttuurien omistajuuteen, käyttöön, kulttuuriperintöstatukseen ja tuotteistamiseen väistämättä liittyviä yhteiskunnallisia ja moraalisia jännitteitä, joista Kalevala Korun viimeaikaistenkin toimien yhteydessä on ollut kyse - ja joihin yritys lienee nimensä myötä tuomittu sotkeutumaan vastaisuudessakin.

Syksyn ja kevään keskustelujen osalta on kiintoisaa tarkastella sitä tunnevetoista ja moralistista retoriikkaa, jolla kulttuuripoliittisia ja juridisia tulkintoja ja linjanvetoja tehtiin. Syy tuomita Kalevala Korun toiminta keväällä liittyi yrityksen haluun kieltää ammattikorkeakoulussa lopputyötään tekevää Mimosa Sukasta käyttämästä tavaramerkkiään sen sisältämän Kalevala-sanan vuoksi. Lisäksi se liittyi spesifimpään vaatimukseen estää Sukasen kulttuurimatkailuhankkeelta yhteistyö koruja, kelloja tai taide- ja koriste-esineitä valmistavien tahojen kanssa. Ohjaavana kontekstina tämän jupakan taustalla oli kuitenkin Kalevala Korun kaupallisia kasvoja kiillottanut syksyinen brändiuudistus, jossa yritys approprioi nimenomaan Kalevala-sanan uudeksi logokseen - ja sanan referentti on tässä yhteydessä nähdäksemme sekä Kalevala kirjallisena teoksena että kokonaisvaltaisempana "kalevalaisena mytologiana" (ks. Tarkka et al. 2019). Sen nostattamalta moralistiselta hygienialta eivät välttyneet folkloristitkaan, joiden tapana onkin reagoida kohdatessaan reflektoimatonta ja essentialisoivaa Kalevala-puhetta - usein omista autenttisuuskäsityksistään käsin.

Julkisessa keskustelussa Kalevala Koru sai nopeasti "pahiksen" roolin ja sen toimet leimattiin muun muassa brändi-itsemurhaksi (Twitter \#1). Kesken jupakan Kalevala Korun omistava Kalevalaisten naisten liitto puolustautui huomauttamalla puheenjohtajansa Ildikó Lehtisen välityksellä, että Kalevala Korun itsensä voisi laskea jo osaksi "suomalaista kulttuuriperintöä" (HS 9.3.2021). Kun abstrakti kulttuuripolitiikan työkalu siis näin ottaa liikeyrityksen muodon ja esittää sen nimissä opinnäytetyötään tekevälle yrittäjälle tekijänoikeusteitse vaatimuksia, ei ole vaikea nähdä kulttuuriperinnön toteuttavan tässä keskeistä rooliaan hegemonisen nimeämisvallan välineenä (esim. Anttonen 2009). Samalla väite Kalevala Korusta kansallisena kulttuuriperintönä palautuu takaisin kysymykseen koruyhtiön alkuperäisistä medievalistisia ja nationalistisia tavoitteita ajaneista valikointiprosesseista.

Mimosa Sukasen vastine, jossa Kalevala-sana (toim. huom.) "ei ole kenenkään omaisuutta vaan suomalaisten immateriaalista kulttuuriperintöä", sai monen kansalaisen ja todennäköisesti myös folkloristin hyväksynnän. Oikeuden päätöksessä sen todettiinkin vastanneen "yleistä oikeustajua". Samalla vastine edusti populistis-humanistis-nationalistisesta pohjavireestä - samoin kuin referentiaalisesta epätarkkuudesta - voimansa ammentavaa kulttuuriperintöpuhetta. Tällaiselle puheelle on luonteenomaista stereotyyppisten kansallisuus-, luokka- ja sukupuolikäsitysten vahvistaminen (esim. Smith 2020). Näin tehdessään se kuitenkin helposti häivyttää esimerkiksi Kalevalankin taustalla olevia historiallisia, etnisiä ja kielellisiä juonteita näkymättömiin. Vaikka jupakassa törmäsivät erilaiset lähtökohdat kulttuuriperintömäärittelyihin, palautuvat ne samankaltaisiin menneisyyden valikoinnin käytäntöihin.

$* * *$

Eloren vuoden 2021 kevätnumerossa käydään lisää keskusteluja perinteen ja kulttuuriperinnön olemuksista ja niihin liittyvistä valikoinneista. Marko Lambergin artikkelissa tarkastellaan Suomen ja sen itäisten ja kaakkoisten lähialueiden suullisen kansanperinteen kuvauksia esimodernin ajan Tukholmasta. Suomen-, karjalan- ja inkerinkielisen (runomuotoisen) ja 
toisaalta myös ruotsinkielisen (proosamuotoisen) perinteen analyysi nostaa näkyville sen, miten kansanperinneaineistoissa "toiseksi" miellettyjen alueiden ja paikkojen kuvaukset heijastavat sekä niihin liitettyjä yliluonnollisia ja arjesta toiseutettuja elementtejä että niiden yhteyksiä materiaaliseen maailmaan. Joonas Ahola taas tuo artikkelissaan esille, miten kalevalamittaiset runolaulut, niiden laulajat ja niiden julkaisualustat kytkeytyivät neuvostoideologiaan 1900-luvun Venäjän Karjalassa. Aholan artikkeli osoittaa, mihin perinteen, kulttuuriperinnön, omistajuuden kysymysten ja politiikan kytkökset voivat äärimmillään viedä.

\section{Kirjallisuus}

Anttonen, Pertti. 2009. Kulttuurin, perinteen ja perinnön kysymyksiä. Elore 16(1), 1-7. https://doi.org/10.30666/elore.78777

Fewster, Derek. 2006. Visions of Past Glory. Nationalism and the Construction of Early Finnish History. Helsinki: Suomalaisen Kirjallisuuden Seura.

Holtorf, Cornelius. 2013. On Pastness: A Reconsideration of Materiality in Archaeological Object Authenticity. Anthropological Quarterly 86(2), 427-443. https://doi.org/10.1353/ anq.2013.0026

Ikäheimo, Janne \& Tiina Äikäs. 2017. Constructing a trumped-up future with the pastness of the present? Neo-relics and archaeological heritage. World Archaeology 49(3), 388-403. https://doi.org/10.1080/00438243.2017.1333922

Immonen, Visa. 2006. Ars archaeologica - Katsaus muinaistieteeseen kirjallisuuden, kuvataiteiden ja teatterin pauloissa. Muinaistutkija 4/2006, 11-27.

Smith, Laurajane. 2020. Emotional Heritage. Visitor Engagement at Museums and Heritage Sites. London \& New York: Routledge.

Tarkka, Lotte, Heidi Haapoja-Mäkelä \& Eila Stepanova. 2019. Kalevalaisuus, kieli-ideologiat ja suomalaisuuden myytit. Teoksessa Ulla Piela, Pekka Hakamies, \& Pekka Hako (toim.), Eurooppa, Suomi, Kalevala: Mikä mahdollisti Kalevalan? Helsinki: Suomalaisen Kirjallisuuden Seura, 79-106.

Twitter \#1. Kalevala Korun Twitter-tili, 2.3.2021. Saatavilla: https://twitter.com/KalevalaKoru/ status/1366729956072505346. (Linkki tarkistettu 6.6.2021.)

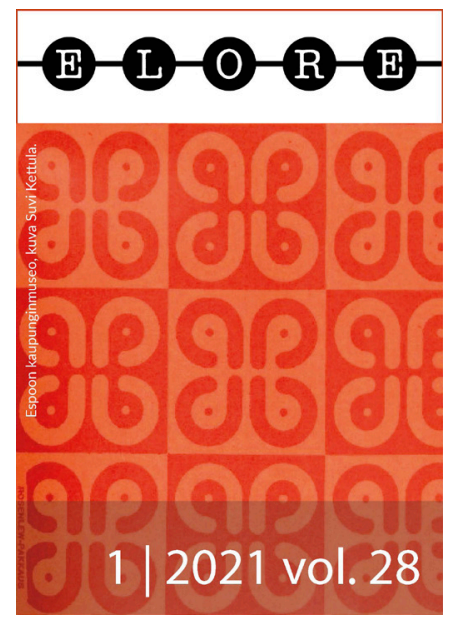

Elore 1-2021:n kansikuvana on Heikintorin hannunvaakunoin kuvioitua käärepaperia, jota valmistettiin noin 1968-1979. Espoon kaupunginmuseo, kuva Suvi Kettula. Kuvalähde Finna.fi. 